\title{
Determination of Total Flavonoid Contents and Antioxidant Activity of Leucaena Leucocephala Leaves's Extract
}

\section{*Taupik Hidayat, Baharuddin Hamzah \& Minarni Rama Jura}

Pendidikan Kimia/FKIP - Universitas Tadulako, Palu - Indonesia 94119

Received 04 March 2020, Revised 06 April 2020, Accepted 05 May 2020

doi: 10.22487/j24775185.2020.v9.i2.pp70-77

\begin{abstract}
The study of the determination of total flavonoid contents and antioxidant activity of extract of Leucaena leucocephala leaves had been carried out using UV-Vis spectrophotometry method. This study aimed to determine the total flavonoid contents and the antioxidant power of Leucaena leucocephala extract. Extraction of chemical content from Leucaena leucocephala was carried out by the maceration method using absolute ethanol. The total flavonoid contents from sample extract were taken up for absorption at wavelength $510 \mathrm{~nm}$ and $700 \mathrm{~nm}$. The variation of the concentration of Leucaena leucocephala leaves's extract was respectively 20, 40, 60, and $80 \mathrm{ppm}$. The results of the study showed that total flavonoid contents of extracts of Leucaena leucocephala leaves was $2.242 \mathrm{~g} / 100$ grams. The antioxidant activity of Leucaena leucocephala leaves's extract was carried out using DPPH (1,1diphenyl-2-pikilhidazil) and the measurement of absorption was at a wavelength of $517 \mathrm{~nm}$, and by varying the sample concentration. Positive control used was vitamin C solution with the same variation of exctract's concentration. The results showed that the $I C_{50}$ values of Leucaena leucocephala leaves's extract and vitamin $C$ were 175.388 and $28.907 \mathrm{ppm}$. Based on the IC $\mathrm{C}_{50}$ data it can be stated that the antioxidant vitamin $C$ was stronger than the Leucaena leucocephala leaves's extract which was classified as a weak type of natural antioxidant.
\end{abstract}

Keywords: Antioxidants, leucaena leucocephala leaves, DPPH, free radicals

\section{Pendahuluan}

Petai cina (Leucaena leucocephala) adalah salah satu tumbuhan yang dapat digunakan sebagai obat (Sartinah, dkk., 2010). Petai cina merupakan sejenis pohon polong-polongan, dengan tinggi mencapai 18 meter, bercabang banyak dan kuat serta daun menyirip rangkap. Salah satu bagian tanaman yang bisa digunakan sebagai obat adalah daun.

Daun petai cina merupakan bagian tanaman yang mengandung beberapa senyawa aktif. Herani, dkk. (2017) mengidentifikasi kandungan senyawa aktif dalam ekstrak daun petai cina dengan uji KLT. Hasil uji pada ekstrak daun petai cina menunjukkan bahwa ekstrak mengandung senyawa saponin, alkaloid, tanin dan flavonoid.

Aderibigbe, dkk. (2011) melakukan penelitian pada minyak petai cina, hasil analisis menunjukkan bahwa minyak daun petai cina mengandung protein kasar $31.1 \%$, dan metabolisme energi sebesar $2573.26 \mathrm{kkal} / \mathrm{kg}$. Minyak petai cina juga mengandung sterol (berupa $55 \% \beta$ sitosterol), alkohol, triterpenoid, tokoferol ( $\alpha$-tokoferol), glikolipida, hidrokarbon dan karotenoid serta $26-29 \%$ asam-asam lemak jenuh dan $71-73 \%$ asam-asam lemak tdak jenuh. Daun petai cina oleh masyarakat biasanya digunakan sebagai obat bengkak. Pemanfaatannya dengan cara menghancurkannya di dalam mulut atau meremasnya menggunakan tangan, kemudian ditempelkan pada bagian yang bengkak (Sartinah, dkk. 2010). Akan tetapi masyarakat khususnya di daerah Palu Sulawesi Tengah kurang memanfaatkan petai cina dengan baik, masyarakat Palu biasanya hanya menggunakan petai cina sebagai pakan ternak. Oleh karena itu perlu dilakukan penelitian lebih lanjut tentang manfaat dari daun petai cina, guna memberikan pengetahuan ilmiah kepada masyarakat bahwa petai cina dapat digunakan sebagai antioksidan.

Antioksidan merupakan suatu substansi yang pada konsentrasi kecil secara signifikan mampu menghambat atau mencegah oksidasi pada substrat (Isnindar, dkk., 2011). Antioksidan juga merupakan zat penghambat reaksi oksidasi akibat radikal bebas yang dapat menyebabkan kerusakan asam lemak tak jenuh, membran

*Correspondence

Taupik Hidayat

e-mail: taupikhhidayat13@gmail.com

(C) 2020 the Author(s) retain the copyright of this article. This article is published under the terms of the Creative Commons Attribution License 4.0, which permits unrestricted non-commercial use, distribution, and reproduction in any medium, provided the original work is properly cited. 
dinding sel, pembuluh darah, basa DNA dan jaringan lipid sehingga menimbulkan penyakit. Radikal bebas didefinisikan sebagai molekul yang memiliki satu atau lebih elektron yang tidak berpasangan pada orbital luarnya (Fessenden \& Fessenden, 1986). Untuk mencapai kestabilan atom atau molekul, radikal bebas akan bereaksi dengan molekul disekitarnya untuk memperoleh pasangan elektron. Reaksi ini akan berlangsung terus menerus dalam tubuh dan bila tidak dihentikan akan menimbulkan berbagai penyakit seperti kanker, jantung, katarak, penuaan dini, serta penyakit degeneratif lainnya (Kikuzaki, dkk., 2002). Suatu tanaman dapat memiliki aktivitas antioksidan apabila mengandung senyawaan yang mampu menangkal radikal bebas seperti fenol dan flavonoid.

Flavonoid adalah golongan senyawa polifenol yang diketahui memiliki sifat sebagai penangkap radikal bebas, penghambat enzim hidrolisis dan oksidatif, dan bekerja sebagai antiinflamasi (Pourmorad, dkk., 2006).

Aktivitas sebagai antioksidan dimiliki oleh sebagian besar flavonoid disebabkan adanya gugus hidroksi fenolik dalam stuktur molekulnya. Ketika senyawa-senyawa ini bereaksi dengan radikal bebas, mereka membentuk radikal baru yang distabilisasi oleh efek resonansi inti aromatik (Cuvelier, dkk., 1994).

Senyawa-senyawa flavonoid adalah senyawa-senyawa polifenol yang mempunyai 15 atom karbon, terdiri dari dua cincin benzena yang dihubungkan menjadi satu oleh rantai linier yang terdiri dari tiga atom karbon. Sebagian besar senyawa flavonoid mempunyai aktivitas sebagai antiinflamasi, anti tumor, anti oksidan dan anti hipertensi (Latifah, 2015).

Flavonoid berperan sebagai antioksidan dengan cara mendonasikan atom hidrogennya, yang akan di ikat oleh senyawa radikal (Latifah, 2015). Menurut Sarastani (2002) kebanyakan sumber antioksidan alami adalah tanaman yang mengandung senyawa fenol yang tersebar di seluruh bagian tanaman baik di kayu, biji, daun, buah, akar, bunga maupun serbuk sari.

Telah banyak penelitian mengenai tanaman petai cina baik biji maupun daunnya, diantaranya peneliti uji potensi ekstrak daun petai cina (Leucaena leucocephala) sebagai anti bakteri staphylococcus epidermis dan efek penyembuhan luka eksis pada mencit BALB C. Ternyata hasil dari uji kepekaan menunjukan adanya hambat sebesar $14 \mathrm{~mm}$. Hal ini menunjukan bahwa ekstrak daun petai cina memiliki kemampuan dalam menghambat pertumbuhan bakteri Staphylococcus epidermidis yang biasanya menjadi penghuni kulit dan sering menyebabkan infeksinosokominal (Wahid, dkk., 2010).

Tulisan ini dimaksudkan untuk menentukan seberapa besar aktivitas antioksidan dari ekstrak daun petai cina.

\section{Metode}

Alat yang digunakan dalam penelitian ini adalah neraca analitik, shaker, Seperangkat alat rotary vacum evaporator, spektofotometer UVVis, corong, tabung reaksi, labu ukur, gelas ukur, Blender, ayakan 80 mesh, kertas saring whatman No. 45, Tissue, Erlenmeyer, Batang pengaduk, Pipet tetes. Bahan yang digunakan dalam penelitian ini yaitu daun petai cina, etanol absolut (Merck), Larutan Buffer pH 1 dan pH 4,5 (Merck) dan DPPH (Aldrich).

\section{Preparasi Sampel}

Daun petai cina agak tua dipetik kemudian dicuci dengan air mengalir hingga bersih, kemudian daun petai cina tersebut dikering anginkan selama beberapa hari dengan tidak terkena sinar matahari langsung, setelah kering daun kemudian diblender hingga halus selanjutnya diayak menggunakan ayakan 80 mesh.

\section{Ekstraksi Sampel}

Daun petai cina kering yang sudah dihaluskan ditimbang 60 gram, selanjutnya diekstraksi menggunakan metode maserasi dengan pelarut etanol hingga terekstrak sempurna. Daun petai cina kering direndam dalam pelarut etanol absolute $600 \mathrm{~mL}$, dilakukan pengadukan menggunakan shaker selama 90 menit, kenudian sampel didiamkan selama 3 x 24 jam sambil sekali-kali diaduk. Setelah 3 x 24 jam filtrat yang diperoleh disaring. Selanjutnya yaitu memekatkan hasil ekstraksi dengan menggunakan rotary vacum evaporator.

\section{Analisis Kadar Flavonoid}

Memasukan ekstrak daun petai cina $5 \mathrm{~mL}$ kedalam 2 buah tabung reaksi. Pada setiap tabung dimasukkan berturut-turut $5 \mathrm{~mL}$ larutan buffer $\mathrm{pH}$ 1 pada tabung satu dan tabung kedua dimasukkan larutan buffer $\mathrm{pH}$ 4,5. Selanjutnya absorbansi kedua tabung diukur menggunakan spektrofotometer UV-Vis pada panjang gelombang $510 \mathrm{~nm}$ dan $700 \mathrm{~nm}$ (Rezky, 2017).

\section{Uji Aktivitas Antioksidan}

\section{Pembuatan Larutan DPPH}

Larutan induk DPPH 1000 ppm dibuat dengan cara memasukan $25 \mathrm{mg}$ serbuk DPPH kemudian memasukannya kedalam labu ukur $25 \mathrm{~mL}$ lalu menambahkan etanol absolut sampai tanda batas.

Larutan DPPH 200 ppm dibuat dengan cara mengambil $5 \mathrm{~mL}$ larutan DPPH $1000 \mathrm{ppm}$ dan memasukannya kedalam labu ukur $25 \mathrm{~mL}$ kemudian menambahkan etanol absolut sampai tanda batas.

\section{Pembuatan Larutan Blanko}

Larutan blanko dibuat dengan cara mengambil $12.5 \mathrm{~mL}$ larutan DPPH $200 \mathrm{ppm}$ dan 
memasukannya kedalam labu ukur $25 \mathrm{~mL}$ kemudian menambahkan etanol absolut sampai tanda batas.

\section{Pembuatan Larutan Ekstrak}

Larutan ekstrak 1000 ppm dibuat dengan cara mengambil $25 \mathrm{mg}$ ekstrak daun petai cina kemudian dimasukan kedalam labu ukur $25 \mathrm{~mL}$, selanjutnya dilarutkan dengan menambahkan etanol absolut sampai tanda batas.

Larutan ekstrak 200 ppm dibuat dengan cara mengambil $5 \mathrm{~mL}$ larutan ekstrak 1000 ppm dan memasukannya kedalam labu ukur $25 \mathrm{~mL}$ kemudian menambahkan etanol absolut sampai tanda batas.

\section{Pembuatan Larutan Pembanding Vitamin C}

Larutan pembanding vitamin C 1000 ppm dibuat dengan cara mengambil $25 \mathrm{mg}$ Vitamin $\mathrm{C}$ dimasukan kedalam labu ukur $25 \mathrm{~mL}$, selanjutnya dilarutkan dengan menambahkan etanol absolut sampai tanda batas.

Larutan pembanding vitamin C 200 ppm dibuat dengan cara mengambil $5 \mathrm{~mL}$ larutan vitamin C 1000 ppm dan memasukannya kedalam labu ukur $25 \mathrm{~mL}$ kemudian menambahkan etanol absolute sampai tanda batas.

\section{Pembuatan Larutan Uji}

\section{Pembuatan Larutan Uji Ekstrak Daun Petai Cina}

Larutan ekstrak $200 \mathrm{ppm}$ dibuat seri konsentrasi mulai dari 20, 40, 60, dan 80 ppm dengan cara mengambil secara berturut-turut 2.5, 5, 7.5 dan $10 \mathrm{~mL}$ larutan ekstrak $200 \mathrm{ppm}$. Kemudian dimasukan kedalam labu ukur $25 \mathrm{~mL}$, selanjutnya menambahkan $5 \mathrm{~mL}$ larutan DPPH kemudian volumenya dicukupkan dengan menambahkan etanol absolut sampai tanda batas.

\section{Pembuatan Larutan Uji Vitamin C}

Larutan vitamin C $200 \mathrm{ppm}$ dibuat seri konsentrasi mulai dari $20,40,60$, dan $80 \mathrm{ppm}$ dengan cara mengambil secara berturut-turut 2.5 , 5, 7.5 dan $10 \mathrm{~mL}$ larutan ekstrak $200 \mathrm{ppm}$. Kemudian dimasukan kedalam labu ukur $25 \mathrm{~mL}$, selanjutnya menambahkan $5 \mathrm{~mL}$ larutan DPPH kemudian volumenya dicukupkan dengan menambahkan etanol absolut sampai tanda batas.

\section{Pengukuran Serapan Blanko, Larutan Uji Ekstrak, dan Larutan Uji Vitamin C}

Pengukuran serapan dilakukan menggunakan spektrofotometri UV-Vis, absorbansi diukur pada panjang gelombang $517 \mathrm{~nm}$. Pengukuran dilakukan ditempat yang tidak terkena sinar matahari langsung (Bahriul, 2014).

\section{Hasil dan Pembahasan}

Berdasarkan penelitian yang telah dilakukan mengenai analisis kadar flavonoid ekstrak etanol daun petai cina (Leucaena leucocephala), maka hasilnya dapat dilihat pada Tabel 1 .

Tabel 1. Hasil analisis kadar flavonoid

\begin{tabular}{|c|c|c|c|}
\hline \multicolumn{2}{|c|}{ Absorbansi } & \multirow{2}{*}{$\begin{array}{c}\text { Kadar total } \\
\text { flavonoid }(\mathrm{mg} / \mathrm{L})\end{array}$} & \multirow{2}{*}{$\begin{array}{c}\text { Kadar total } \\
\text { flavonoid }(\mathrm{g} / 100 \mathrm{~g})\end{array}$} \\
\hline $510 \mathrm{~nm}$ & $700 \mathrm{~nm}$ & & \\
\hline 2.564 & 1.648 & \multirow{2}{*}{2242.340} & \multirow{2}{*}{2.242} \\
\hline 2.330 & 1.559 & & \\
\hline
\end{tabular}

Data hasil pengukuran absorbansi ekstrak daun petai cina dan pembanding vitamin $\mathrm{C}$ yang telah ditambahkan dengan larutan DPPH sesuai variasi konsentrasi disajikan pada Tabel 2.

Data persen inhibisi dari masing-masing sampel daun petai cina dan pembanding vitamin $\mathrm{C}$ disajikan pada Tabel 3.

Nilai $\mathrm{IC}_{50}$ dan daya antioksidan yang diperoleh dari hasil perhitungan akhir yaitu untuk ekstrak daun petai cina diperoleh $\mathrm{IC}_{50}$ sebesar 175.388 ppm, sedangkan vitamin $\mathrm{C}$ diperoleh $\mathrm{IC}_{50}$ sebesar 28.907 ppm. Hasil tersebut menunjukan bahwa ekstrak daun petai cina dapat dikategorikan sebaggai antioksidan lemah sedangkan vitamin $\mathrm{C}$ dapat dikategorikan sebagai antioksidan sangat kuat.

\section{Analisis Kadar Flavonoid Total}

Mengkonsumsi makanan atau sayuran yang mengandung flavonoid diharapkan bisa menunjang kebutuhan gizi dan meningkatkan kekebalan tubuh. Flavonoid berfungsi sebagai antiinflamasi dan antioksidan yang mampu menekan efek peradangan, selain itu flavonoid juga dapat membantu mengurangi rasa sakit (analgesik). Lektin, Saponin, Tanin yang terkandung dalam daun petai cina berfungsi dalam membantu regenerasi kulit atau menstimulasi pembentukan sel-sel baru yaitu dengan menghambat produksi jaringan luka yang berlebihan, sedangkan alkaloid berfungsi sebagai antiseptic (Rohman, dkk., 2016). 
Tabel 2. Hasil pengukuran absorbansi daun petai cina dan vitamin $\mathrm{C}$

\begin{tabular}{ccccc}
\hline \multirow{2}{*}{ Konsentrasi (ppm) } & \multicolumn{2}{c}{ Absorbansi } & \multicolumn{2}{c}{ Absorbansi Rata-Rata } \\
\cline { 2 - 5 } & Daun Petai Cina & Vitamin C & Daun Petai Cina & Vitamin C \\
\hline \multirow{2}{*}{20} & 0.975 & 0.727 & & \\
& 0.975 & 0.727 & 0.975 & 0.725 \\
& 0.976 & 0.721 & & \\
& 0.972 & 0.658 & & 0.644 \\
40 & 0.943 & 0.636 & 0.959 & \\
& 0.963 & 0.637 & & 0.62 \\
60 & 0.828 & 0.623 & & \\
& 0.826 & 0.616 & 0.827 & 0.543 \\
& 0.827 & 0.62 & & \\
\hline
\end{tabular}

Tabel 3. Data persen inhibisil

\begin{tabular}{cccccc}
\hline \multirow{2}{*}{$\begin{array}{c}\text { Konsentrasi } \\
(\mathrm{ppm})\end{array}$} & \multirow{2}{*}{$\begin{array}{c}\text { Abs. } \\
\text { Blanko }\end{array}$} & $\begin{array}{c}\text { Daun Petai } \\
\text { Cina }\end{array}$ & Vitamin C & $\begin{array}{c}\text { Daun Petai } \\
\text { Cina }\end{array}$ & Vitamin C \\
\hline 20 & & 0.975 & 0.725 & 28.884 & 47.119 \\
40 & \multirow{2}{*}{1.371} & 0.943 & 0.644 & 31.218 & 53.027 \\
60 & & 0.826 & 0.620 & 39.752 & 54.778 \\
80 & & 0.791 & 0.543 & 42.305 & 60.394 \\
\hline
\end{tabular}

Analisi kadar flavonoid total dilakukan dengan menggunaka metode spektrofotometri UV-Vis, merujuk pada Hukum Lambert Beer dimana intensitas sinar datang yang dipantulkan atau diteruskan oleh medium merupakan fungsi eksponensial dari konsentrasi dan tebal laju larutan yang dilalui sinar. Prinsipnya bias cahaya monokromatik melalui suatu medium, maka sebagian cahaya tersebut diserap, sebagian dipantulkan dan sebagiannya lagi dipancarkan (Sastrohamidjojo, 2007).

Hasil pengukuran spektrofotometer UV-Vis diperoleh absorbansi sebesar 0.145. Data yang sudah diperoleh damasukan kedalam persamaan untukmenentukan kandungan total flavonoid, melalui perhitungan diperoleh total flavonoid sebesar $2.242 \mathrm{~g} / 100$ gram, dari hasil yang sudah diperileh dapat diketahui bahwa daun petai cina memiliki potensi untuk dijadikan sebagai obat alami.

\section{Uji Aktivitas Antioksidan}

Metode yang digunakan dalam pengujian aktivitas antioksidan adalah metode serapan radikal DPPH. Metode ini digunakan berdasarkan kemampuan antioksidan untuk menghambat radikal bebas dengan mendonorkan atom hydrogen kepada DPPH, yang merupakan radikal bebas yang stabil pada suhu kamar. Metode ini dipilih karena merupakan metode yang sederhana, mudah dan menggunakan sampel dalam jumlah yang sedikit dengan waktu yang singkat (Molyneux, 2004). Metode pengujian ini berdasarkan pada kemampuan substansi antioksidan tersebut dalam menetralisir radikal bebas. Senyawa tersebut dapat dikatakan memiiki aktivitas antioksidan apabila senyawa tersebut mampu mendonorkan atom hidrogennya pada radikal bebas DPPH. Radikal bebas yang digunakan adalah DPPH (1,1-diphenyl-2picylhydrazyl).

Aktivitas diukur dengan menghitung jumlah pengurangan intensitas warna ungu DPPH yang sebanding dengan pengurangan konsentrasi larutan DPPH. Peredaman tersebut dihasilkan oleh bereaksinya molekul difenil pikril hidrazil dengan atom hidrogen yang dilepaskan satu molekul komponen sampel sehingga terbentuk senyawa difenil pikril hidrazin dan menyebabkan terjadinya peluruhan warna DPPH dari ungu ke kuning (Zuhra, dkk., 2008).

Pengukuran aktivitas antioksidan secara spektrofotometri dilakukan pada panjang gelombang $517 \mathrm{~nm}$, yang merupakan panjang gelombang maksimum DPPH. Metode uji menggunakan DPPH ini didasarkan pada 
penurunan absorbansi akibat perubahan warna larutan warna DPPH, dimana DPPH akan bereaksi dengan atom hidrogen dari senyawa peredam radikal bebas membentuk DPPH-hidrazin yang lebih stabil. Reagen DPPH yang bereaksi dengan antioksidan akan mengalami perubahan warna dari ungu ke kuning, intensitas warna tergantung kemampuan dari antioksidan (Molyneux, 2004). Pengamatan terhadap intensitas warna pada penelitian ini dilakukan pada konsentrasi 20 ppm,
40 ppm, 60 ppm dan 80 ppm yang bertujuan untuk mengetahui tingkat peredaman warna sebagai akibat adanya senyawa antioksidan yang mampu mengurangi intensitas warna ungu dari DPPH.

Berdasarkan hasil yang diperoleh pada pengukuran absorbansi diperoleh data yang disajikan pada Gambar 1.

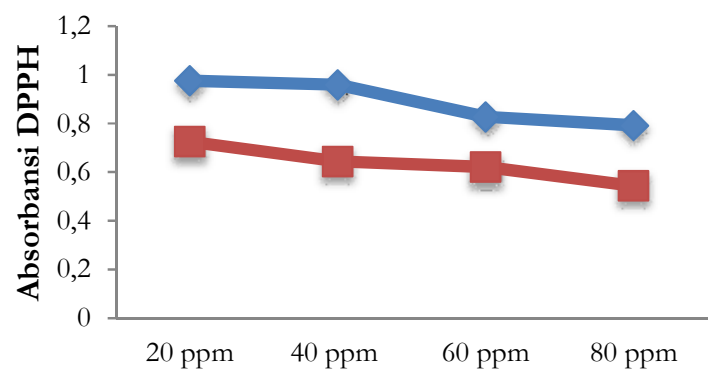

Konsentrasi

Gambar 1. Hubungan absorbansi DPPH dengan konsentrasi ekstrak daun petai cina dan vitamin C ( $\square$ : daun petai cina, a:vitamin $\mathrm{C}$

Berdasarkan data pada Gambar 1, menujukan bahwa nilai absorbansi DPPH semakin berkurang seiring dengan bertambahnya konsentrasi ekstrak daun petai cina dan vitamin C. Hal ini dapat terjadi karena adanya reduksi radikal DPPH oleh antioksidan, dimana semakin tinggi konsentrasi ekstrak daun petai cina maka partikel-partikel senyawa antioksidan yang terkandung akan semakin banyak sehingga semakin besar pula aktivitas antioksidannya dan menyebabkan absorbansi dari DPPH semakin berkurang (Talapessy, dkk., 2013).

Data absorbansi yang diperoleh juga menunjukkan bahwa DPPH yang ditambahkan vitamin $\mathrm{C}$ memiliki nilai absorbansi lebih rendah dibanding DPPH yang ditambahkan daun petai cina, hal ini disebabkan karena perbedaan kandungan senyawa antioksidan, dimana vitamin $\mathrm{C}$ memiliki kandungan senyawa antioksidan yang lebih banyak dibanding daun petai cina hal ini terjadi karena vitamin $\mathrm{C}$ merupakan salah satu senyawa antioksidan yang sangat kuat. Namun, dengan data tersebut dapat diketahui bahwa daun petai cina juga memiliki potensi sebagai senyawa antioksidan meskipun tidak sekuat vitamin C.

Semakin banyaknya senyawa antioksidan akan menyebabkan semakin besar pula peredaman warna ungu dari DPPH. Hal ini dikarenakan oleh banyaknya molekul-molekul antioksidan yang mereduksi radikal DPPH yang menyebabkan terjadinya perubahan warna ungu DPPH menjadi kuning sehingga nilai absorbansi yang diperoleh semakin kecil. Demikian pula dengan DPPH yang ditambahkan pembanding vitamin $\mathrm{C}$, memiliki nilai absorbansi yang lebih kecil dibandingkan nilai absorbansi DPPH yang ditambahkan dengan daun petai cina, hal ini dikarenakan vitamin $\mathrm{C}$ merupakan senyawa antioksidan kuat, dimana jumlah partikel senyawa antioksidan yang terkandung lebih banyak menyebabkan nilai absorbansi DPPH yang diperoleh juga semakin kecil seiring dengan bertambahnya konsentrasi vitamin $\mathrm{C}$.

Berdasarkan hasil pengukuran absorbansi tersebut, dapat ditentukan pula persentase penghambatan radikal bebas oleh ekstrak daun petai cina dan vitamin $\mathrm{C}$ tersebut pada berbagai konsentrasi yang disajikan pada Gambar 2. Berdasarkan data pada Gambar 2 tersebut menunjukkan bahwa persen penghambatan vitamin $\mathrm{C}$ lebih tinggi dibandingkan persen penghambatan ekstrak daun petai cina hal ini disebabkan oleh kandungan senyawa antioksidan yang dimiliki vitamin $\mathrm{C}$ lebih banyak dibandingkan kandungan senyawa antioksidan dari daun Petai Cina. Data tersebut juga menunjukan bahwa daun petai cina memiliki potensi sebagai antioksidan alami, hal ini dapat dilihat dari persen penghambatan daun petai cina dengan larutan pembanding vitamin $\mathrm{C}$ yang tidak terlalu berbeda jauh, dimana selisih persen penghambatan radikal DPPH vitamin $\mathrm{C}$ dan daun petai cina sebesar $20 \%$. 
Data persentase penghambatan ekstrak daun petai cina dan vitamin C pada Gambar 2 menunjukkan bahwa persentase penghambatan radikal bebas dari ekstrak daun petai cina tidaklah terlalu berbeda dengan persentase penghambatan vitamin C. Hal ini membuktikan bahwa ekstrak daun petai cina memiliki kemampuan sebagai antioksidan yang cukup baik. Oleh karena itu, ekstrak daun petai cina bisa dimanfaatkan sebagai bahan antioksidan alami.

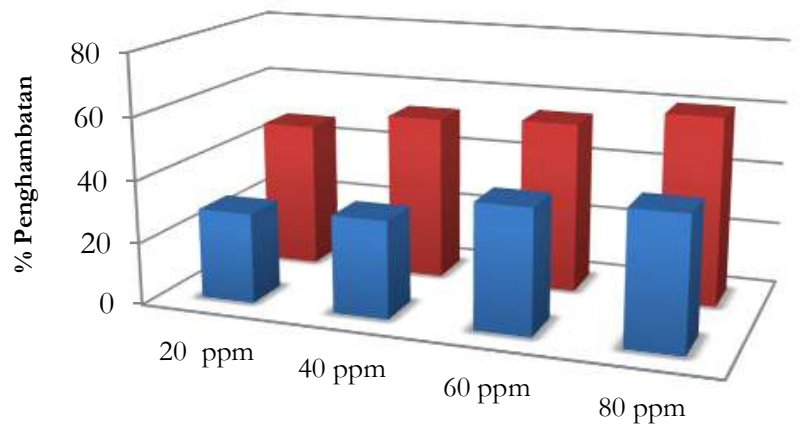

Konsentrasi (ppm)

Gambar 2. Perbandingan persentase penghambatan ekstrak daun petai cina dan vitamin $\mathrm{C}$ ( $\square$ : daun petai Cina, ㅁ: vitamin C)

Pengukuran IC $C_{50}$ Ekstrak Daun Petai Cina dan Vitamin C

Uji antioksidan dari penelitian ini ditentukan menggunakan parameter dari nilai $\mathrm{IC}_{50}$ (Inhibition concentration) utuk menjelaskan kekuatan daya antioksidan dari sampel uji, dalam proses pengujian dilakukan menggunakan metode DPPH. Nilai $\mathrm{IC}_{50}$ diperoleh dari beberapa tahapan yaitu menghitung nilai log konsentrasi sampel uji dan nilai probit untuk masing-masing persentase aktivitas penghambat radikal bebas DPPH dari ekstrak daun petai cina dan vitamin $\mathrm{C}$

Selanjutnya menghubungkan nilai probit dan nilai log konsentrasi yang diperoleh dalam 1 grafik utuh, dimana nilai log konsentrasi dijadikan sebagai sumbu $X$ dan nilai probit digunakan sebagai sumbu Y seperti tampak pada Gambar 3.

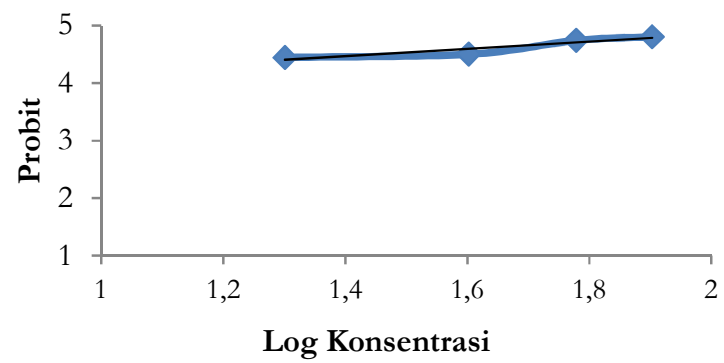

(a)

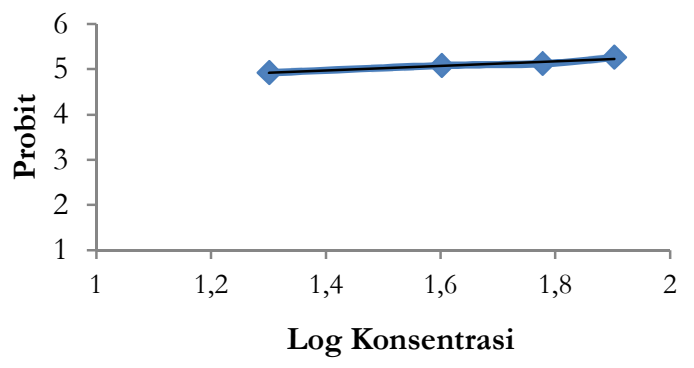

(b)

Gambar 3. Hubungan log konsentrasi dan harga probit pada: (A) daun petai cina, (B) vitamin C 
Berdasarkan Gambar tersebut diperoleh persamaan regresi linear $\mathrm{y}=0.631 \mathrm{x}+3.584$ untuk esktrak daun petai cina, dan $\mathrm{y}=0.514 \mathrm{x}+4.249$ untuk vitamin $\mathrm{C}$ (Pembanding/Kontrol positif). Melalui persamaan regresi yang diperoleh pada Gambar 3, nilai $\mathrm{x}$ dapat ditentukan setelah mengganti nilai $\mathrm{y}=5$ yang merupakan harga probit dari $50 \%$.

Nilai $\mathrm{IC}_{50}$ yang diperoleh dari hasil perhitungan akhir yaitu untuk ekstrak daun petai cina mempunyai $\mathrm{IC}_{50}$ sebesar $175.388 \mathrm{ppm}$, sedangkan $\mathrm{IC}_{50}$ yang dihasilkan vitamin $\mathrm{C}$ sebesar 28.907 ppm. Hal ini menjelaskan bahwa kemampuan menangkap radikal bebas ekstrak daun petai cina termasuk dalam golongan lemah dikarenakan nilai $\mathrm{IC}_{50}$ yang diperoleh dari perhitungan lebih dari $150 \mathrm{ppm}$.

Berdasarkan nilai $\mathrm{IC}_{50}$ yang diperoleh dapat dijelaskan pula bahwa vitamin $\mathrm{C}$ sebagai pembanding termasuk antioksidan yang lebih kuat jika dibandingkan dengan ekstrak daun petai cina yang digunakan sebagai sampel pada penelitian ini, dimana nilai $\mathrm{IC}_{50}$ dari vitamin $\mathrm{C}$ jauh lebih kecil, semakin kecil nilai $\mathrm{IC}_{50}$ maka semakin kuat aktifitas antioksidannya, hal ini bisa dilihat dari nilai $\mathrm{IC}_{50}$ untuk vitamin $\mathrm{C}$ yang diperoleh yaitu $28.907 \mathrm{ppm}$. Berdasarkan hal ini pula dapat disimpulkan bahwa daun petai cina memiliki potensi untuk dijadikan sebagai antioksidan alami.

\section{Kesimpulan}

Ekstrak daun petai cina memiliki total flavonoid sebesar $2.242 \mathrm{~g} / 100$ gram dan nilai $\mathrm{IC}_{50}$ yang diperoleh dalam penelitian ini sebesar $175.388 \mathrm{ppm}$. Dari nilai ini dapat diketahui bahwa ekstrak daun petai cina memliki aktivitas antioksidan yang lemah, dimana dilihat dari nilai $\mathrm{IC}_{50}$ yang lebih dari $150 \mathrm{ppm}$ hal ini sebanding dengan kadar flavonoid yang diperoleh, dimana dari 60 gram sampel yang diekstraksi hanya menghasilkan kadar flavonoid sebesar 2.242 $\mathrm{g} / 100$ gram.

\section{Ucapan Terima Kasih}

Ucapan terima kasih penulis sampaikan kepada laboran Laboratorium Kimia Fakultas Keguruan dan Ilmu Pendidikan yang telah memberikan bimbingan dan masukan dalam menyelesaikan penelitian ini.

\section{Referensi}

Aderibigbe, S. A., Adetunji, O. A., \& Odeniyi, M. A. (2011). Antimicrobial and pharmaceutical properties of the seed oil of leucaena leucocephala (lam) de wit (liguminosae). African Journal of Biomedical Research, 14(1), 63-68.

Bahriul, P., Rahman, N., \& Diah, A. W. M. (2014). Uji aktivitas antioksidan ekstrak daun salam (syzygium polyanthum) dengan menggunakan 1,1-Difenil-2-Pikrihidrazil. Jurnal Akademika Kimia, 3(3), 143-149.

Cuvelier, M. E., Richards, H., \& Berset, C. (1994). Comparison of the antioxidative activity of some acid phenols: structureactivity relationship. Journal Bioscience Biotechnology Biochemistry, 56(2), 324-325.

Fessenden, R. J. \& Fessenden, J. S. (1986). Kimia organik, cetakan ketiga (Pudjaatmaka $\mathrm{AH}$, penerjemah). Jakarta: Erlangga.

Herani, M., \& Oktarina, R. Z. (2017). Uji efektivitas daun petai cina (leucaena glauca) sebagai anti inflamasi dalam pengobatan luka bengkak. Jurnal Majority, 6(1),86-89.

Isnindar, Wahyuono, S., \& Setyowati, E. P. (2011). Isolasi dan identifikasi senyawa antioksidan daun kesemek (diospyros kaki thunb.) dengan metode DPPH (2,2-Difenil-1 Pikrilhidrazil). Majalah Obat Tradisional, 16(3), 157-164.

Kikuzaki, H., Hisamoto, M., Hirose, K., Akiyama, K., \& Taniguchi, H. (2002). Antioxidants properties of ferulic acid and it's related compound. Journal of Agricultural and Food Chemistry, 50(7), 2161-2168.

Latifah. (2016). Identifikasi golongan senyawa flavonoid dan uji aktivitas antioksidan pada ekstrak rimpang kencur (Leucaena leucocephala) dengan metode DPPH. Thesis Tidak Diterbitkan. Malang: Universitas Islam Negeri Maulana Malik Ibrahim.

Molyneux, P. (2004). The use of the stable free radical diphenylpicrylhydrazyl (DPPH) for estimating antioxidant activity. Songklanakarin Journal Science Technology, 26(2), 211-219.

Pourmorad, F., Hosseinimehr, S. J., \& Shahabimajd, N. (2006). Antioxidant activity phenol and flavonoid contents of some selected iranian medicinal plants. African Journal of Biotechnology, 5(11), 1142-1145.

Rezky, P. A., Gonggo, S. T., \& Sabang, S. M. (2017) Analisis kadar flavonoid dan fenolat pada kulit buah manggis (garcininia mangostana 1.). Jurnal Akademika Kimia, 6(4), 196-199.

Rohman, S. N., Fuadah, D. Z., \& Girianto, P. W. R. (2016). Efektivitas daun petai cina (leucaena leucocephala) dan daun jarak pagar (jatropha curcas) terhadap proses penyembuhan luka bakar grade II pada tikus putih (rattus novegicus). Jurnal Ilmu Keperawatan, 4(1), 20-33.

Sarastani, D., Suwarna T., Soekarto, T., \& Muchtadi, R. (2002). Aktivitas antioksidan ekstrak dan fraksi ekstrak biji atung. Jurnal Teknologi dan Industri Pangan, 13(2), 149156. 
Sartinah, A., Astuti, P., \& Wahyono, S. (2010). Isolasi dan identifikasi senyawa antibakteri dari daun petai cina (leucaena leucocephala (lam). de wit). Jurnal Majalah Obat Tradisional, 15(3), 22-28.

Sastrohamidjojo, H. (2007). Spektroskopi. Yogyakarta: Liberty.

Talapessy, S., Suryanto, E., \& Yudistira, A. (2013). Uji aktivitas antioksidan dari ampas hasil pengolahan sagu (metroxylon sagu rottb). Jurnal Ilmiah Farmasi, 2(3), 40-44.
Wahid, R. H., Widiani, N., \& Khitmatunnaiz, M. (2010). Uji potensi ekstrak daun petai cina (leucaena leucocephala) sebagai anti bakteri staphylococcus epidermidis dan efek penyembuhan luka eksis pada mencit bal B/C. Jurnal Pelita, 8(2), 17-25.

Zuhra, C. F., Tarigan, J. Br., \& Sihotang, H. (2008). Aktivitas antioksidan senyawa flavonoid dari daun katuk (sauropus androgunus (1) mer). Jurnal Biologi Sumatera, 3(1), 7-10. 